\title{
Measuring the Relationship between Intellectual Capital and Project Managers Competency Model in the Project Oriented Organizations
}

\author{
Kimia SadatMirkamali \\ Department of Public Management, Kerman Branch, Islamic Azad University, Kerman, Iran \\ Email:kmirkamali@yahoo.com
}

SanjarSalajeghe (Corresponding author)

Department of Public Management, Kerman Branch, Islamic Azad University, Kerman, Iran

Email: salajeghe_187@yahoo.com

Received: March 23, 2014 Accepted: April 14, 2014 Published: June 4, 2014

doi:10.5296/rbm.v1i2.5339 URL: http://dx.doi.org/10.5296/rbm.v1i2.5339

\begin{abstract}
This paper introduces a persuaded and sound method to measure the relationship between project managers competency model (PMCD) and intellectual capital covering human capital, structural capital and relational capital in order to provide an effective conceptual model. Project manager competency base model is IPMA Competence Baseline (ICB) and Project Manager Competency Development Framework (PMCDF) includes knowledge, skill, personality, and industry \& organization competence. The final model illustrates results of measurements between the three components of intellectual capital and the five elements project manager competency model. The results are significant because they confirm importance of project managers' competencies. In addition, the study results are so stable and reliable because we use confident instrument to measure indicators.
\end{abstract}

Keywords: Intellectual Capital; Project Managers Competency Model; Effectiveness; Human Capital; Structural Capital 


\section{Introduction}

According to Roos, Pike and Fernstrom (2005) "Intellectual Capital can be define as all nonmonetary and nonphysical resources that are fully or partly controlled by the organization and that contribute to the organization's value creation" (Roos, Pike, \& Fernstrom, 2005). It is the collection of intangible and knowledge-based assets a company (or individual) possesses. Components of intellectual capital include human capital, relationship capital and structural capital (Marr, 2013, Roos, Pike, \& Fernstrom, 2005). Intellectual capital helps to drive success and create value. The success of leading companies such as Amazon, Google, Microsoft, and Wal-Mart is based on their intellectual capital (Marr, 2008).

Of course, one of the most important intangible assets ${ }^{1}$ of these companies is the human capital; in other words, employees! Perhaps if we required the listing of human capital on the balance sheet as an asset and not just a liability, we could begin to properly identify the value of human capital to these companies themselves (Weatherly, 2003). Human capital is the stock of competencies, knowledge, social and personality attributes, including creativity, cognitive abilities, embodied in the ability to perform labor so as to produce economic value (Simkovic, 2013).

Organizations also use competencies to ensure that their personnel performance expectations are aligned with the company's vision and goals. Employers can identify competency gaps and put in place training programs specifically designed to fill these and they can change their human resources to human capital by this strategy. Competency is an observable set of skills, knowledge, abilities, and other characteristics an individual needs to successfully perform work duties or occupational functions (National park service U.S department of the interior, 2010). Competency models ${ }^{2}$ can help organizations align their initiatives to their overall business strategy. By aligning competencies to business strategies, organizations can better recruit and select employees for their organizations (Mulder, 2001). It is important to choose the right people to manage projects (Mark \& Rick, 2004).

In this article has been tried to measure the relationship between intellectual capital and job competency models - each has its own characteristics - in order to design an effective conceptual model for project-oriented organizations such as research ones in energy industry. Case study in this research is considered two hundred project managers of the six research institute in Iran's electric power industry. Today most essential form of energy that is used all over the world is electrical power. Development of power industry, according to the increasing needs routine, one of the most important strategies in the energy industry. Effective research in this area can be very beneficial which is done by a research institute in the Ministry of Energy. However, the research projects do not have required effectiveness that is necessary in this field. One of the reasons could be mismanagement of the project. Accordance to statistics in these institutions, project delivery latency is high.

\footnotetext{
${ }^{1}$ Examples of intangible assets, also called intangible capital, include intellectual capital (patent formulas, product designs, and process technology, i.e., the methods that delineate the steps in a process), goodwill, and human capital.

${ }^{2}$ Competency Model: A framework that describes the full range of competencies required to be successful in a particular occupation.
} 
No one would claim that every project that fails is the result of poor management. A poorly funded or ill-conceived project will fail regardless of the skills of the project manager or project team. But project mismanagement plays a significant role in many project failures (Gould \& Freeman, 2004). Project management quality is defined as fulfilling the requirements agreed for the management of the project. The optimum situation for a project organization is that all the people, the project team and resource providers involved in project management are competent to carry out their work and to take individual responsibility (ICB-IPMA, 2003). Competencies are the knowledge, understanding, practical and thinking skills needed to perform effectively to the standards required in employment. They are identified and demonstrated through sets of behaviors that encompass the skills, knowledge, abilities and personal attributes that are critical to successful role accomplishment (Scottish Community Development Centre, 2007).

\section{Research Model}

\subsection{Intellectual Capital}

Intellectual capital means gathering all the organization members' intellect and their usage. Stewart (1997) defined intellectual capital as a complex of useful knowledge that includes an organization's processes, technologies, patents, employees' skills, and information about customers, suppliers and stakeholders (Stewart, 1997). Sveiby (1998) highlighted in his definition of intellectual capital two basic aspects; one that is human-specific, reflected in the knowledge, experiences, and brainpower of employees, and another one that is organizationspecific, reflected in the know ledge resources stored in an organization's databases, processes, culture and philosophy (Suha, 2014). As such, it is concluded that the collection of an organization's knowledge-based (intangible) resources and their flows, and the conversion of the resulting knowledge into competitive advantage, value, and profit, are what form the core of an organization's intellectual capital (Harrison \& Sullivan, 2000; Bontis, 2001; Wang \& Chang, 2005). Intellectual capital factors: (Ramezan, 2013)

- Human capital

- Structural capital

- Relationship capital (Customer)

\subsubsection{Human Capital}

The first definitions of Human Capital (Mincer, 1958; Schultz, 1961; Johnson, 1960; Marshall, 1961; Lev e Schwartz, 1961, 1971) came from the Fisher's capital definition (1930). Human Capital refers to the combination of factors held by individuals and by a company's workforce. It may comprise knowledge, ability and technical skills; personal features such as wit, energy, attitude, confidence, commitment, learning ability; it includes aptitude, imagination and creativity; to be willing to share information, make part of a team and focus on organization goals (Fitz-enz, 2000). Human capital is the sometimes tacit knowledge that resides in the heads of the employees, ranging from the professional staff, the R\&D experts, to factory workers and marketing people (Sveiby, 1997). It is especially important to 
professional service firms as it constitutes the core competency of the organization, but remains difficult to codify.

\subsubsection{Structural Capital}

Structural capital covers a number of different notions related to the company rather than to the specific employee. Structural capital is divided into organizational capital (innovation and process capital) and customer capital (Edvinsson \& Malone, 1997), in short what is "left at the office when the employees go home" (p.11). Structural capital is the knowledge embodied in the organization, in the structures built to support the staff in their intellectual work. It helps the organization in turning individual human intelligence into knowledge that can be measured and developed on an organizational level. Without good and reliable structures for leveraging human capital it will only remain in the minds of the employees. In other words, by leveraging human capital and making it useful for the whole organization, the employees create structural capital. (Ordóñez de Pablos 2004, Bontis 1998)

\subsubsection{Relationship Capital (Customer)}

Relationship capital should be seen as part of the firm's structural capital. Human capital is argued to include competence, attitude and intellectual agility, but not relationship capital, which is only seen as belonging to the structural capital category. The way, in which relationship structural capital is defined, however, focuses on relationships with "customers, suppliers, alliance partner, shareholders and other stakeholders" (Roos et al., 1997). I.e., in their view relationship capital corresponds to interorganizational relationships. Relational capital consists of a wide variety of external relationships between the organization and its customers, suppliers, competitors, and partners. Suggested measurements of relational capital include seeing it as a function of the longevity of the relationship, based on the assumption that the value of relational capital increases with time (Bontis, 1998).

Components of intellectual capital in this study is in accordance with Table 1.

Table 1. Components of intellectual capital

\begin{tabular}{|c|c|c|}
\hline Factors & Components & Method of Evaluation \\
\hline Human Capital & $\begin{array}{l}\text {-Empowerment (competence, a sense } \\
\text { of the work). } \\
\text { - Recruitment } \\
\text { - Education } \\
\text { - Evaluation of human } \\
\text { - Ability to communicate }\end{array}$ & $\begin{array}{l}\text { - Evaluation of human resource } \\
\text { - Comments by respondents } \\
\text {-* All of the above were asked } \\
\text { employees in form of questionnaire }\end{array}$ \\
\hline $\begin{array}{l}\text { Structural } \\
\text { Capital }\end{array}$ & $\begin{array}{l}\text { - Innovation } \\
\text { - Team work } \\
\text { - Structure } \\
\text { - Process } \\
\text { - Access to information }\end{array}$ & $\begin{array}{l}\text { - Training and personal research } \\
\text { include : } \\
1 \text { - Number of educational Classes } \\
2 \text { - Classes influence on employees' } \\
\text { skills and abilities }\end{array}$ \\
\hline
\end{tabular}




\begin{tabular}{|l|l|l|}
\hline & $\begin{array}{l}\text { - Leadership } \\
\text { - Hierarchy } \\
\text { - Culture }\end{array}$ & $\begin{array}{l}\text { - Personnel ability to problem } \\
\text { solving effectively in different } \\
\text { projects, including research and } \\
\text { development. (Based on the number } \\
\text { of items provided }) \\
4 \text { - Approved budgets for the } \\
\text { organizational research }\end{array}$ \\
$\begin{array}{l}\text { Relationship } \\
\text { capital } \\
\text { (Customer) }\end{array}$ & $\begin{array}{l}\text { - Customer satisfaction } \\
\text { - Good vision of the organization with } \\
\text { other people \& other organizations. }\end{array}$ & $\begin{array}{l}\text { All of the above were asked } \\
\text { employees in form of questionnaire }\end{array}$ \\
\hline & $\begin{array}{l}\text { - Comments by respondents } \\
\text { questionnaire }\end{array}$ \\
\hline
\end{tabular}

\subsection{Project Management Competency Model}

Competence-based approach in education and training provides the opportunity to identify and develop people with the competencies required for performing the job. Competence is a term which is widely used but which has come to mean different things to different people. It is generally accepted, however, as encompassing knowledge, skills, attitudes and behaviors that are causally related to superior job performance (Boyatzis 1982). Based on Scott Parry's (1998) definition, a competency is a cluster of related knowledge, attitudes, skills, and other personal characteristics that:

- Affects a major part of one's job (i.e., one or more key roles or responsibilities)

- Correlates with performance on the job

- Can be measured against well-accepted standards

- Can be improved via training and development

- Can be broken down into dimensions of competence.

To understand competency requirements of a job role, they are often represented pictorially and competencies are mapped, with competencies existing on a hierarchy (Sandwith, 1993). A competency model is a descriptive tool that identifies the competencies needed to operate in a specific role within $a(n)$ job, occupation, organization, or industry. Simply stated, a competency model is a behavioral job description that must be defined by each occupational function and each job (Fogg, 1999). Depending on the work and organizational environment, a group of 7 to 9 total competencies are usually required of a particular job and depicted in a competency model (Shipman et al., 2000). Rothwell (2002) explains that there are core competencies that are required of all workers. This would include knowledge, skills and abilities (commonly referred to asKSAs), as well as soft skills or behaviors (Michelle, 2008).

The project management competency is the capability to manage projects professionally, by applying best practices regarding the design of the project management process, and the application of project management methods. Project management competencies require 
knowledge and experience in the subject, which enables the project to meet its deadlines and objectives (Gareis \& Huemann, 1999). The Project Management Partners Competency Model was developed from the observable behaviors of successful, professional project managers in a variety of application areas. It provides a consistent, coherent structure for assessing the capabilities of current and prospective project managers.

There are lots of competency models for project managers. Table2 shows the standards that survived in this research. Defining a body of knowledge and developing guides and standards for practice as a basis for education, training and associated certification or qualification programs are activities generally associated with the formation of a profession. It is therefore not surprising that, associated with growing interest in and application of project management, professional associations such as the Project Management Institute (PMI®), International Project Management Association (IPMA), Association for Project Management (APM, UK), the Australian Institute of Project Management (AIPM), and the Japan Project Management Forum (JPMF) have taken an active role in this area. Responding to the needs of industry, governments in the United Kingdom, South Africa and Australia have resourced the development of standards for project management as part of their national qualification frameworks. Project management professional associations have also taken an active interest in the development of standards underpinning such qualification frameworks. (Global Performance Based Standards for Project Management Personnel, 2003)

Table 2. Global Standards for developing Project Manager Competency Model

\begin{tabular}{|l|l|l|}
\hline Rows & Abbreviation & Standards \\
\hline & APM & Association for Project Management \\
\hline & AQF & Australian Qualifications Framework \\
\hline & ICB & IPMA Competence Baseline \\
\hline & IPMA & International Project Management Association \\
\hline & JPMF & Japan Project Management Forum \\
\hline & NQF & $\begin{array}{l}\text { National Competency Standards for Project Management } \\
\text { Australia }\end{array}$ \\
\hline & NVQ/SVQ & $\begin{array}{l}\text { National Qualification Framework } \\
\text { Qualification Vocational Qualification/ Scottish }\end{array}$ \\
\hline & OSCEng & Occupational Standards Council for Engineering \\
\hline & PMCC & Project Management Professionals Certification Center \\
\hline & PMSGB & Project Management Standards Generating Body \\
\hline & PMBOK & Project Management Body of Knowledge \\
\hline
\end{tabular}

In this research, PMCDF (Project Manager Competency Development Framework) and 


\section{Macrothink}

PMBOK (Project Management Body of Knowledge) standards and IPMA competence baseline were considered as main models, but only structure and elements of the PMCDF standard is adapted to the research because it is not classified to the different classification of the projects. Also beyond PMBOK standard, the three areas of change management, difficulties \& barriers project management and metrics management are created.

The PMCD Framework, which has been in the works since 1997, is PMI's first standard to address the theme of "Improving the Performance of Project Personnel." This is an important step in PMI's continuing commitment to define the body of knowledge supporting the project management profession, and to develop standards for its application. The PMCD Framework is intended to assist project managers and those aspiring to be project managers in guiding their professional development. The PMCD Framework identifies competencies in three dimensions-Knowledge, Performance and Personal (Rebecca, 2002). It was developed to apply generically to all project managers, regardless of the nature, type, size, or complexity of projects they may be engaged in managing. Also it is consistent with A Guide to the Project Management Body of Knowledge (PMBOK ${ }^{\circledR}$ Guide) Edition. Figure 1 shows the dimensions of competency in the PMCD framework. Also figure 2 shows overview of project management knowledge areas and project management processes in PMBOK standards.

As shown in figure1, knowledge, performance and personal competencies of project manager are core competencies that project managers need to have to do their practices well. Understanding and applying the knowledge, tools, and techniques that are recognized as best practices for effective project manager. Demonstrate project management proficiency in three dimensions (Ibid, 2002):

Knowledge- what a project manager knows about the application of processes, tools, and techniques in project activities.

Performance -how a project manager applies project management knowledge to meet project requirements.

Personal -how a project manager behaves when performing activities in a project environment. 


\section{Macrothink}

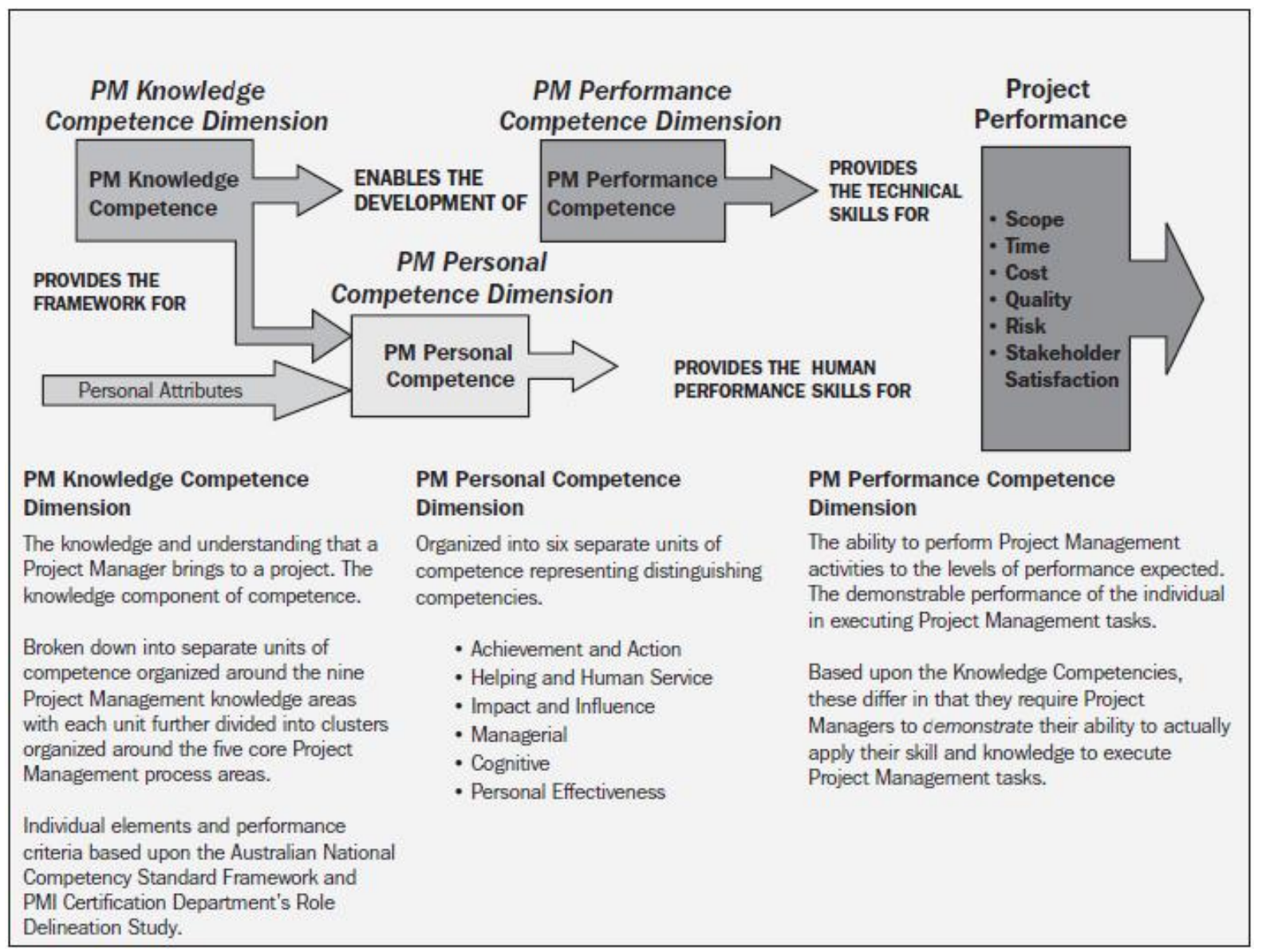

Figure 1. Dimensions of competency in the PMCD framework

\subsubsection{Knowledge Competency}

Knowledge Competency demonstrates an understanding of knowledge specific to a technical, professional, or administrative field of work through the application of related procedures, principles, theories or concepts. The ability to update job knowledge and effectively utilize available resources and technology. Knowledge competence is not detailed within the PMCD Framework as it is specifically addressed in the PMP Examination Specification. The intent is to ensure that individuals, their organizations, and associated industry professional bodies apply an appropriate process for the assessment, development, and recognition of competence in project managers (PMI, 2007). 


\section{MInstitute ${ }_{\text {Mnk }}^{\text {Macrothink }}$}

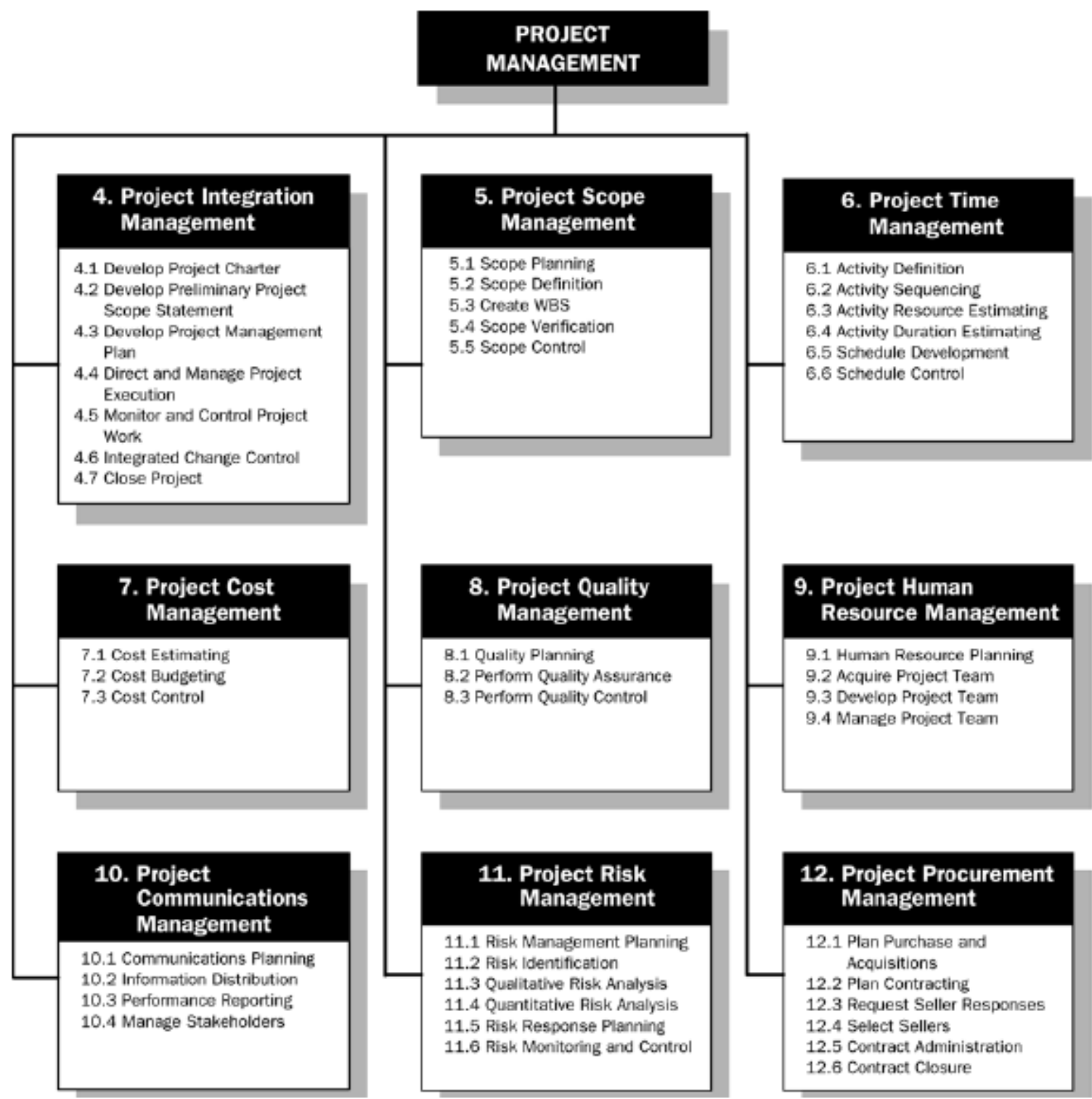

Figure 2. Overview of project management knowledge areas and project management processes in PMBOK

Project Manager Knowledge Competence means; what the project manager knows about the application of processes, tools, and techniques for project activities (Ibid, 2007).

\subsubsection{Performance Competency}

Performance competence is what the project manager is able to do or accomplish by applying their project management knowledge. Individuals will demonstrate their Performance Competence by applying their knowledge to a project and delivering the planned outcomes. Each individual skill that reflects project management good practice needs to be assessed. To assess Performance or Skill Competence, endorsed standards or baselines are required for each skill against which: Individuals are able to measure and plan their progress towards competence. Organizations are able to design performance measurement instruments, design job 
specifications, employment specifications and individual development programs (Ibid, 2007)

Performance Competence puts into practice the knowledge that a project manager possesses. It is generally accepted that there is a causal link between project manager competence and project success. Performance Competence is a key component of overall project manager competence. In other words, knowledge is the outcome of the assimilation of information through learning. Knowledge is the body of facts, principles, theories and practices that is related to a field of work or study but skills means the ability to apply knowledge and use know-how to complete tasks and solve problems.

\subsubsection{Personal Competency}

Personal Competencies are those behaviors, attitudes, and core personality characteristics that contribute to a person's ability to manage projects. Project management is a people-oriented profession. It is important for a project manager to possess skills that enable an effective interaction with others. Personal Competencies describe such skills. Improvements in personal competence enhance a project manager's ability to use knowledge and performance competence effectively on projects (Ibid, 2007). Personal Competencies are grouped into the following six (6) units:

-Communicating - effectively exchanges accurate, appropriate, and relevant information with stakeholders using suitable methods.

-Leading-guides, inspires, and motivates team members and other projects take holders to manage and overcome issues to effectively achieve project objectives.

- Managing - effectively administers the project through deployment and use of human, financial, material, intellectual, and intangible resources.

- Cognitive Ability - applies an appropriate depth of perception, discernment, and judgment to effectively direct a project in a changing and evolving environment.

-Effectiveness - produces desired results by using appropriate resources, tools, and techniques in all project management activities.

-Professionalism-conforms to an ethical behavior governed by responsibility, respect, fairness, and honesty in the practice of project management.

\subsubsection{Industrial \& Organizational Competency}

Industrial and organizational competences are considered as the Contextual Competence range to describe the project management competence elements related to the context of the project. This range covers the project manager's competence in managing relations with the line management organization and the ability to function in a project focused organization. The ICB contains 11 contextual competence elements like; project orientation, business, finance, legal, health, safety, security \& environment, system, products \& technology and so on. In this research, two ranges of industrial and organizational competences are considered as the Contextual Competences. Elements and dimensions of organizational and industrial competencies are shown in Table 3. 


\section{Macrothink}

Table 3. Elements and dimensions of organizational and industrial competencies

\begin{tabular}{|c|c|c|}
\hline Rows & $\begin{array}{c}\text { Organizational } \\
\text { Competencies' Elements }\end{array}$ & $\begin{array}{l}\text { Dimensions of organizational } \\
\text { competencies }\end{array}$ \\
\hline 1. & legal topics & $\begin{array}{l}\text { - Legal topics of current laws' organization } \\
\text { - Legal issues related to research and } \\
\text { technology }\end{array}$ \\
\hline 2. & Organizational knowledge & $\begin{array}{l}\text { - Understanding Organizational Structure } \\
\text { and Organization } \\
\text { - Mission and Strategic Plan } \\
\text { - Familiarity with organizational } \\
\text { regulations and guidelines }\end{array}$ \\
\hline 3. & $\begin{array}{l}\text { Familiarity with technology } \\
\text { and research }\end{array}$ & $\begin{array}{l}\text { - Familiar with the technology, research } \\
\text { methods of problem solving and research } \\
\text { - General familiarity with the technology }\end{array}$ \\
\hline 4. & $\begin{array}{ll}\text { Familiarity } & \text { with } \\
\text { characteristics } & \text { of research } \\
\text { projects } & \end{array}$ & $\begin{array}{l}\text { - Familiarity with research areas } \\
\text { - Familiar with the methods of data } \\
\text { collection } \\
\text { - Familiarity with feasibility studies of } \\
\text { research projects Familiar with the } \\
\text { algorithm, the phases and structure of } \\
\text { research projects } \\
\text { - Creation ideas and select the best ideas }\end{array}$ \\
\hline 5. & HSE Management & $\begin{array}{l}\text { - } \text { Planning of HSE } \\
\text { - Implementation and control of HSE }\end{array}$ \\
\hline 6. & $\begin{array}{l}\text { Benchmarking } \\
\text { comparative studies }\end{array}$ & $\begin{array}{ll}- & \text { Modeling } \\
\text { - } & \text { Learning experience }\end{array}$ \\
\hline 7. & knowledge management & $\begin{array}{ll}\text { - } & \text { Knowledge Mining } \\
\text { - } & \text { Acquire the knowledge } \\
\text { - } & \text { Transmission and Distribution of } \\
& \text { Knowledge in Organizations }\end{array}$ \\
\hline 8. & Proficiency in English & - $\quad$ Speaking, Listening, Writing, Reading \\
\hline 9. & Computer skills & $\begin{array}{ll}\text { - } & \text { ICDL } \\
\text { - } & \text { Familiar enough with Relevant software }\end{array}$ \\
\hline 10. & Quality of education & $\begin{array}{l}\text { - GPa quality education courses of } \\
\text { university rankings }\end{array}$ \\
\hline Rows & Industrial Competencies & Dimensions of Industrial competencies \\
\hline 1 & $\begin{array}{l}\text { Familiarity with electricity and } \\
\text { energy industry }\end{array}$ & $\begin{array}{l}\text { - Familiarity with a variety of power plants, } \\
\text { manufacturing, distribution, transmission, } \\
\text { dispatching and Contacts }\end{array}$ \\
\hline 2 & $\begin{array}{l}\text { Familiarity with the Ministry } \\
\text { of Energy and related } \\
\text { industries }\end{array}$ & $\begin{array}{l}\text { - Network management, subsidiaries } \\
\text { distributors / producers and affiliated } \\
\text { companies }\end{array}$ \\
\hline 3 & $\begin{array}{l}\text { Familiarity with technology, } \\
\text { products and services to the } \\
\text { power industry }\end{array}$ & $\begin{array}{l}\text { Familiarity with information technology, } \\
\text { products and services of power industry } \\
\text { and energy production, industrial } \\
\text { processes, power }\end{array}$ \\
\hline
\end{tabular}




\subsection{Hypothesis Development}

Project management as the most important process in project-based organizations can not develop without any care to other factors in the organization. Project Manager Competency Model develops necessary parameters like knowledge, skills, personal characteristics' project managers and important processes of project management. It is useful to develop it appropriately as a basis for the organization's intellectual capital. The project management as a core process in the project-oriented organizations is related to structural capital, relational capital and human capital of the organization. Human-embodied knowledge, which takes the forms of skills, experiences, competencies, talents, creativity, amongst others, make up an organization's human capital (Stewart, 1997; Roos, 1998; Van Buren, 1999; Katila \& Ahuja, 2002; Subramaniam \& Youndt, 2005; Seleim \& Khalil, 2011), and is considered the source, from which ideas and solutions that can enhance existing products, services, and processes in projects and develop project management process.

Structural capital, which reflects organizational knowledge in the forms of technologies, patents, manuals, processes, and culture that are so important to project management process. A project organization is a structure that facilitates the coordination and implementation of project activities. Its main reason is to create an environment that fosters interactions among the team members with a minimum amount of disruptions, overlaps and conflict. One of the important decisions of project management is the form of organizational structure that will be used for the project. The structure defines the relationships among members of the project management and the relationships with the external environment (Paola L. Diaz, 2007). Without good and reliable structures for leveraging human capital it will only remain in the minds of the employees. In other words, by leveraging human capital and making it useful for the whole organization, the employees create structural capital (Ordóñez de Pablos, 2004, Bontis, 1998).

Managing projects involves more than managing the triple constraint. Project stakeholders must also be managed. This course focuses on the key to managing stakeholders - creating an effective project relationship. Building the relationship involves designing an action plan, defining roles and responsibilities, planning for change, and communicating risks. Managing and sustaining relationships is often easier when things are going well - the challenge comes when things aren't going well. The value of the relationship may sometimes be trademarked or otherwise converted into intellectual property of the company. This also includes an understanding of the impact of industry associations and customer needs, and access to the knowledge embedded in customers and partners (Bontis, 1998).

The aforementioned discussion leads to our research hypothesis:

H1: There is a positive and significant relationship between intellectual capital (human, structural, and relational) and project manager's competency model (knowledge, performance, personal, Industrial and Organizational Competencies).

Figure 3 shows the theoretical framework developed in this research, which reflects its hypothesis. Questions of the study are: 
1. How are the characteristics of project managers' competencies in the organizations?

2. How is the status of intellectual capital in the organizations?

3. Are the components of intellectual capital related to project managers' competency model?

3.1 Are any relationship between knowledge competencies of project managers and intellectual capital?

3.2 Are any relationship between skill competencies of project managers and intellectual capital?

3.3 Are any relationship between personal competencies of project managers and intellectual capital?

3.4 Are any relationship between industrial competencies of project managers and intellectual capital?

3.5 Are any relationship between organizational competencies of project managers and intellectual capital?

4. How much is the effectiveness of project managers?

5. Are there any relationship between the components of project managers competencies and effectiveness of project managers?

6. Is there a relationship between intellectual capital and effectiveness of project managers?

7. What are the characteristics of conceptual model for this research?

\section{Research Constructs Operationalisation}

After developing the research model and hypothesis, there is a need to measure the main variables depicted in the research theoretical framework in order to gather primary data for the purpose of testing the research hypothesis. After reviewing relevant studies, a number of items were developed to measure the research constructs and their respective dimensions (See table 4). Accordingly, intellectual capital dimensions were measured through developing items by referring to Bontis (1998); Youndt et al. (2004); Seleim and Khalil (2011), as follows: five items for "human capital", eight items for "structural capital", and two items for "relational capital". Project managers competencies dimensions were measured through developing items by referring to PMCDF model (for knowledge, performance and personal competencies) and opinions of experts using the Delphi technique (for organizational and industrial competencies), as follows: twelve items for knowledge competency, twelve items for performance competency, six items for personal competency, ten items for organizational competency and three items for industrial competency.

Assess the effectiveness of project managers is based on PMCDF model. According to experts and Karan Prakash (2013) model parameters are summarized to18 indicators to assess the effectiveness of project managers. To measure the effectiveness of each component, the questions are designed by top executives will comment on each person. Overview of Project Management, Schedule and Cost Management, Problems and Obstacles Management, Change Management, Communication Management, Stakeholder Expectations Management, Document Management, Risk Management, Quality Management, Procurement Management, Human Resource Management, Measures and Metrics Management, Leadership, Management (management skills and ability to execute), Cognitive skills, Be effective, Professionalism and HSE management are the main indicators to evaluate effectiveness of project managers. 


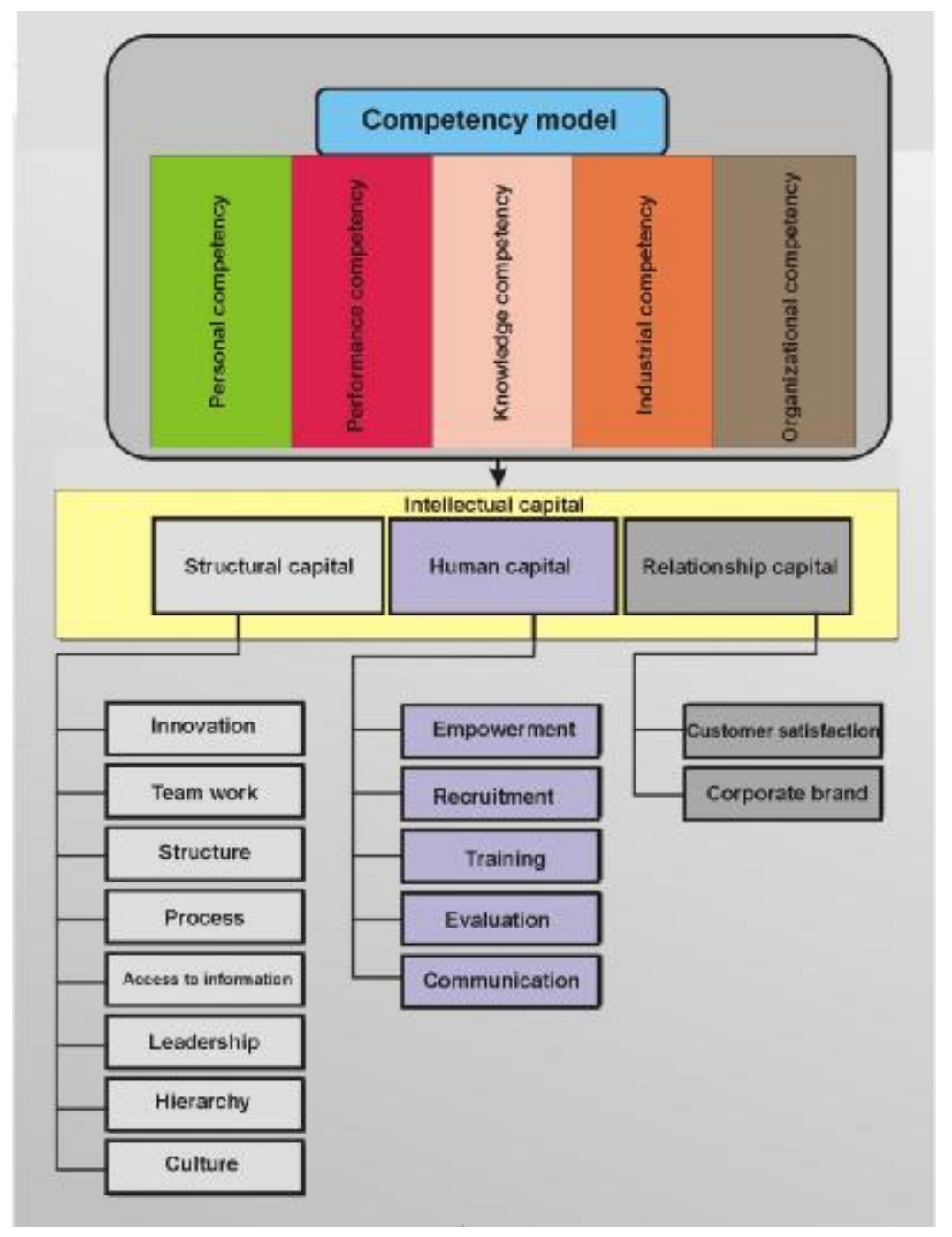

Figure 3. Research Theoretical Framework

\section{Research Methodology}

The research followed a survey design where the structured and unstructured exams were used to evaluate the competencies of project managers. Also, it followed a survey design in which has been used structured and unstructured questionnaires to evaluate the dimensions' characteristics of intellectual capital. The research population consisted of all seven energy research institutes operating in Iran. All of seven energy research institutes invited to participate in research survey. Six out of seven energy research institutes agreed to participate, which represented $90.0 \%$ of the whole population and the unit of analysis consisted of project managers . The population who participated in survey is about two hundred persons. Based on total population, the response rate was $95.0 \%$ which is considered a very high one (Dillman, 1978; Hair, Anderson, Tatham, \& Black, 1998). 


\section{Macrothink}

Table 4. Measurement of the research constructs

\begin{tabular}{|c|c|c|c|c|c|}
\hline \multicolumn{6}{|c|}{ Project Manager Competency Model } \\
\hline & Knowledge & Perfol & Personal & Organizational & Industrial \\
\hline 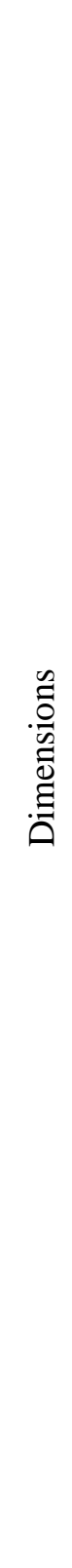 & 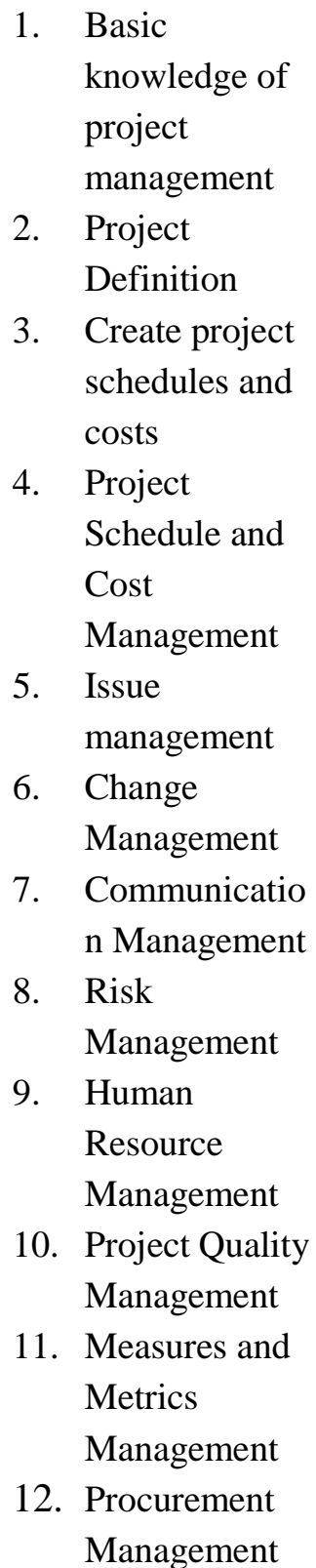 & $\begin{array}{l}\text { 1. Scope } \\
\text { Management } \\
\text { 2. Time } \\
\text { Management } \\
\text { 3. Cost } \\
\text { Management } \\
\text { 4. Quality } \\
\text { Management } \\
\text { 5. Human } \\
\text { Resource } \\
\text { Management } \\
\text { 6. Communicatio } \\
\text { n Management } \\
\text { 7. Risk } \\
\text { Management } \\
\text { 8. Procurement } \\
\text { Management } \\
\text { 9. Change } \\
\text { Management } \\
\text { 10.Issue } \\
\text { Management } \\
\text { 11. Metric } \\
\text { Management } \\
\text { 12. Basic } \\
\text { knowledge of } \\
\text { project } \\
\text { management }\end{array}$ & $\begin{array}{l}\text { 1. Communicatio } \\
\text { ns } \\
\text { 2. Leadership } \\
\text { 3. Management } \\
\text { 4. Cognitive } \\
\text { skills } \\
\text { 5. Be effective } \\
\text { 6. Being a } \\
\text { professional }\end{array}$ & $\begin{array}{l}\text { 1.Legal topics } \\
\text { 2. Organization } \\
\text { al knowledge } \\
\text { 3.Familiarity } \\
\text { with } \\
\text { technology } \\
\text { and research } \\
\text { 4.Familiarity } \\
\text { with the } \\
\text { characteristic } \\
\text { s of research } \\
\text { projects } \\
\text { 5.HSE } \\
\text { Management } \\
\text { 6.Benchmarkin } \\
\text { g and } \\
\text { comparative } \\
\text { studies } \\
\text { 7.Knowledge } \\
\text { management } \\
\text { 8.Proficiency } \\
\text { in English } \\
\text { 9.Computer } \\
\text { skills } \\
\text { 10. Quality } \\
\text { of } \\
\text { education }\end{array}$ & $\begin{array}{l}\text { 1.Familiarit } \\
\text { y with } \\
\text { electricity } \\
\text { and } \\
\text { energy } \\
\text { industry } \\
\text { 2.Familiarit } \\
\text { y with the } \\
\text { Ministry } \\
\text { of Energy } \\
\text { and } \\
\text { related } \\
\text { industries } \\
\text { 3.Familiarit } \\
\text { y with } \\
\text { technolog } \\
\text { y, } \\
\text { products } \\
\text { and } \\
\text { services } \\
\text { to the } \\
\text { power } \\
\text { industry }\end{array}$ \\
\hline
\end{tabular}




\begin{tabular}{|c|c|c|c|c|}
\hline & \multirow[b]{2}{*}{$\begin{array}{l}\text { PMCDF model, } \\
\text { PMI (2007). } \\
\text { Method of } \\
\text { evaluation: Exam; } \\
105 \text { questions } \\
\text { multiple-choice test } \\
\text { method's of } \\
\text { TenStep company }\end{array}$} & \multirow[b]{2}{*}{$\begin{array}{l}\text { PMCDF model, } \\
\text { PMI (2007). } \\
\text { Method of } \\
\text { evaluation: Exam; } \\
36 \text { questions with } \\
\text { the correct } \\
\text { descriptive project } \\
\text { management } \\
\text { expertise } \\
\text { consensus of } \\
\text { experts }\end{array}$} & \multirow[b]{2}{*}{$\begin{array}{l}\text { PMCDF model, } \\
\text { PMI (2007). } \\
\text { Method of } \\
\text { evaluation: Exam; } \\
25 \text { questions } \\
\text { personality using } \\
\text { DISC, test - } \\
\text { multiple choice }\end{array}$} & \multirow[b]{2}{*}{$\begin{array}{l}\text { Opinions of experts using the } \\
\text { Delphi technique (2014). } \\
\text { Method of evaluation: Exam; } \\
20 \quad \text { questions for } \\
\text { organizational competency } \\
\text { and } 8 \text { questions for industrial } \\
\text { competency in manner of } \\
\text { multiple choice test. }\end{array}$} \\
\hline 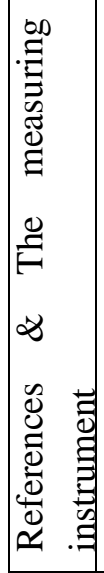 & & & & \\
\hline \multicolumn{5}{|c|}{ Intellectual Capital } \\
\hline & Human Capital & Structur: & 1 Capital & \\
\hline 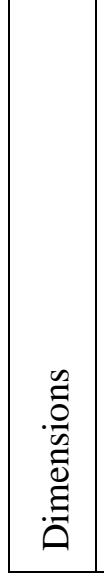 & $\begin{array}{l}\text { 1. Empowerment } \\
\text { (competence, a } \\
\text { sense of the } \\
\text { work). } \\
\text { 2. Recruitment } \\
\text { 3. Education } \\
\text { 4. Evaluation of } \\
\text { human } \\
\text { Resources } \\
\text { 5. Ability to } \\
\text { communicate }\end{array}$ & $\begin{array}{l}\text { 1. Innovation } \\
\text { 2. Team work } \\
\text { 3. Structure } \\
\text { 4. Process } \\
\text { 5. Access to inform } \\
\text { 6. Leadership } \\
\text { 7. Hierarchy } \\
\text { 8. Culture }\end{array}$ & ation & $\begin{array}{l}\text { 1. Customer satisfaction } \\
\text { 2. Good vision of the } \\
\text { organization with other } \\
\text { people \& other } \\
\text { organizations. }\end{array}$ \\
\hline 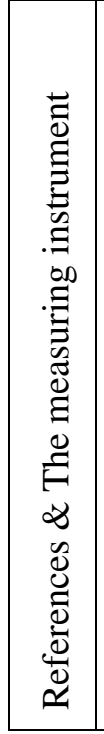 & $\begin{array}{l}\text { Evaluation of } \\
\text { human resource } \\
\text { - Comments by } \\
\text { respondents } \\
\text {-* All of the above } \\
\text { were asked } \\
\text { employees in form } \\
\text { of questionnaire }\end{array}$ & $\begin{array}{l}\text { - Training and } \\
\text { include : } \\
1 \text { - Number of edu } \\
2 \text { - Classes influe } \\
\text { skills and abilities } \\
3 \text { - Personnel ability } \\
\text { effectively in } \\
\text { including research } \\
\text { (Based on the } \\
\text { provided ) } \\
4 \quad-\text { Approved } \\
\text { organizational resea } \\
* \text { All of the above w } \\
\text { in form of questionn }\end{array}$ & $\begin{array}{l}\text { personal research } \\
\text { cational Classes } \\
\text { nce on employees' } \\
\text { to problem solving } \\
\text { different projects, } \\
\text { and development. } \\
\text { number of items } \\
\text { budgets for the } \\
\text { ch } \\
\text { ere asked employees } \\
\text { aire }\end{array}$ & $\begin{array}{l}\text { - Comments by respondents } \\
\text {-asked employees in form of } \\
\text { questionnaire }\end{array}$ \\
\hline
\end{tabular}

As shown in Table 5, more than two third of the respondents have high educational level in master and doctorate degree. 
Table 5. Research respondents' characteristics

\begin{tabular}{|l|l|l|}
\hline \multicolumn{1}{|c|}{ Respondent's characteristics } & \multicolumn{1}{l|}{ Frequency } & Percentages \\
\hline Educational Level & 0 & 0.0 \\
\hline Diploma & 25 & 12.5 \\
Bachelor & 145 & 72.5 \\
Master & 30 & 15.0 \\
Doctorate & 25 & 13.0 \\
\hline Experience Years & 82 & 40.0 \\
\hline Less than 5 years & 55 & 27.0 \\
5-less than 10 years & 30 & 15.0 \\
10-less than 15 years & 8 & 5.0 \\
15-less than 20 years & \multicolumn{2}{l|}{} \\
20 years and more & 146 & 54.0 \\
\hline Gender & 54 & 27.0 \\
\hline Male & \multicolumn{2}{l}{} \\
Female & 12 & 6.0 \\
\hline Age & 85 & 42.0 \\
\hline Less than 25 years & 76 & 38.0 \\
25-less than 35 years & 22 & 11.0 \\
35-less than 45 years & 5 & 3.0 \\
45-less than 55 years & & \\
55 years and more &
\end{tabular}

\section{Analysis and Result}

\subsection{Validity and Reliability}

The content and face validity of the research instrument was assured through following a number of procedures, which are: (a) conducting a thorough examination of the relevant literature addressing intellectual capital and project manager competency model, (b) designing the measurement items by referring to well-known studies, in which researchers have developed and used reliable scales to measure the same constructs, (c) conducting a pilot study phase before starting the survey, whereby five academics specialized in the areas of human resource management, project management, and intellectual capital management acted as referees for the questionnaire. In addition, twenty practitioners working in six research institutes were interviewed and asked for their comments and suggestions regarding the phrasing and design of the questionnaire items. The collective feedback gained was used to refine the design of the questionnaire and its items.

With regard to construct validity, Exploratory Factor Analysis (EFA) was performed to test the components of the intellectual capital and project manager competency model, in terms of identifying the dimensions that exists measurement items. To conduct the EFA, four assumptions were followed (Hair et al., 1998; Field, 2000): (1) sampling adequacy; (2) the minimum eigen value for each factor to be one; (3) a factor loading of 0.40 for each item as the threshold for item retention, and (4) varimax rotation was used. To conduct the EFA, the 
variables of study should be normally distributed; this makes it possible to generalize the results of the analysis beyond the sample collected (Field, 2000). Therefore, a Kolmogorov-Smirnov (K-S) test was performed. The result of the test indicated that the data are not normally distributed. To accommodate this non-normality, the research constructs were transformed by taking the square root transformation and logarithm transformation. Data transformation is an acceptable way to reduce the variability of data, as long as the same mathematical application is performed on every observation. According to Stevens (2009), data transformation is allowed because it simply involves applying a mathematical process to the data to reduce the variability.

The reliability of constructs was measured by calculating Cronbach's alpha coefficient for the factors that resulted from EFA. The closer the value of Cronbach's alpha is to one, the higher the degree of internal consistency among items (Hair et al., 1998; Field, 2000). Table 6 shows all constructs were highly reliable, ranging from 0.830 to 0.965 .

Table 6. Reliability of research constructs

\begin{tabular}{|l|c|c|}
\hline \multicolumn{1}{|c|}{ Construct } & Number of items & Cronbach's alpha \\
\hline Knowledge Competency & 12 & 0.965 \\
Performance Competency & 12 & 0.952 \\
Personal Competency & 6 & 0.854 \\
Organizational Competency & 10 & 0.933 \\
Industrial Competency & 3 & 0.837 \\
Human Capital & 5 & 0.897 \\
Structural Capital & 8 & 0.890 \\
Relationship Capital & 2 & 0.830 \\
\hline
\end{tabular}

\subsection{Descriptive Analysis and Correlation}

Results of data analysis are presented in this section of the research. In the data analysis, the frequency tables and graphs using bar (column) describes some project managers demographic characteristics (age, education, work experience, work unit, and gender) are presented in Table 5. Then, the characteristics of project managers competencies (knowledge competency, technical competency, interpersonal competency, industrial and organizational competencies) and efficacy and effectiveness of them examine the by using histogram and box. Pearson and Spearman correlation test determine the relationships between project managers' competencies and intellectual.

Competency test results show that the project manager's competency characteristics are desired. Proportion test are used to investigate this hypothesis by comparing scores of administrators competency model components. In this test, the null hypothesis and alternative hypothesis are as follows: 
- Null hypothesis: the characteristics of project manager's competencies are not in good condition. (More than half of project managers competencies based on component scores have not achieved a satisfactory score.)

- Alternative hypothesis the characteristics of project manager's competencies are in good condition. (More than half of project managers competencies based on component scores are getting a good score.)

As shown in Table 6, the results obtained from 200 subjects, the proportion of managers with appropriate competency scores 0.98 and the p-value is less than 0.001 , so the null hypothesis at the 0.05 is rejected. The project managers' competencies characteristics are desired.

Table 6. Project Managers Competency Characteristics

\begin{tabular}{|l|l|}
\hline Sample & 200 \\
\hline Number of favorable & 196 \\
\hline Compared with a sample & 0.98 \\
\hline P-value & Less than 0.001 \\
\hline
\end{tabular}

Also, based on the results of the intellectual capital questionnaires, intellectual capital conditions are not suitable for project-based research institutes. Proportion test are used to investigate this hypothesis by comparing scores of administrators intellectual capital components. In this test, the null hypothesis and alternative hypothesis are as follows:

- Null hypothesis: the intellectual capital of the samples is not desirable. (More than half of managers have not achieved a satisfactory score based on scores in intellectual capital components.)

- Alternative hypothesis: the intellectual capital of the samples is desirable. (More than half of managers have achieved a satisfactory score based on scores in intellectual capital components.)

As shown in Table 7, the results obtained from 200 subjects, the proportion of respondents with optimal intellectual capital is 0.32 and the $\mathrm{P}$-value is equal to one, so the null hypothesis at the level of 0.05 is not rejected. The intellectual capital of the samples is not desirable.

Table 7. Intellectual capital Characteristics at Project Oriented Research Institutes

\begin{tabular}{|l|c|}
\hline Sample & 200 \\
\hline Number of favorable & 64 \\
\hline Compared with a sample & 0.32 \\
\hline P-value & 1 \\
\hline
\end{tabular}

\subsection{Hypothesis Testing}

The research main hypothesis was tested by regressing project managers' competency model 
and intellectual capital, using multiple regression analysis. The Pearson's, Spearman's and Kendall's correlation coefficient are shown in Table 8. Amount of P-value at all correlation coefficient is more than 0.05 and it means there is no direct correlation between project managers' competencies and intellectual capital in the project oriented research institutes.

Table 8. The correlation coefficient between components of project managers' competencies and intellectual capital

\begin{tabular}{|c|c|c|c|}
\hline \multicolumn{2}{|c|}{ Components' Relationships } & The correlation coefficient & P-value \\
\hline \multirow{3}{*}{$\begin{array}{l}(\mathrm{KC}) \quad \& \\
(\mathrm{IC})\end{array}$} & Pearson's correlation coefficient & -0.028 & 0.696 \\
\hline & Spearman's correlation coefficient & -0.014 & 0.847 \\
\hline & Kendall's correlation coefficient & -0.011 & 0.824 \\
\hline \multirow{3}{*}{$\begin{array}{l}(\mathrm{PC}) \quad \& \\
(\mathrm{IC})\end{array}$} & Pearson's correlation coefficient & -0.070 & 0.325 \\
\hline & Spearman's correlation coefficient & -0.049 & 0.493 \\
\hline & Kendall's correlation coefficient & -0.034 & 0.481 \\
\hline \multirow{3}{*}{$\begin{array}{l}(\mathrm{PerC}) \quad \& \\
(\mathrm{IC})\end{array}$} & Pearson's correlation coefficient & -0.009 & 0.904 \\
\hline & Spearman's correlation coefficient & -0.014 & 0.839 \\
\hline & Kendall's correlation coefficient & -0.011 & 0.817 \\
\hline \multirow{3}{*}{$\begin{array}{l}(\mathrm{InC}) \quad \& \\
(\mathrm{IC})\end{array}$} & Pearson's correlation coefficient & -0.104 & 0.141 \\
\hline & Spearman's correlation coefficient & -0.080 & 0.259 \\
\hline & Kendall's correlation coefficient & -0.058 & 0.262 \\
\hline \multirow{3}{*}{$\begin{array}{l}(\mathrm{OC}) \quad \& \\
\text { (IC) }\end{array}$} & Pearson's correlation coefficient & -0.143 & 0.043 \\
\hline & Spearman's correlation coefficient & -0.153 & 0.031 \\
\hline & Kendall's correlation coefficient & -0.105 & 0.034 \\
\hline
\end{tabular}

Although between components of project managers' competencies and effectiveness (E) of project managers are direct relationships as shown in Table 9. According to the significance of regression equations coefficients and significant $\mathrm{P}$-values are less than 0.001 , the regression models are significant at 0.05 . This again confirms that there are the significant relationship between the project managers' competencies components and effectiveness of project managers. Regression equations are;

- Effectiveness $=150.071+0.543 *$ Knowledge Competency $(\mathrm{KC})$

- Effectiveness $=10.801+1.364 *$ Performance Competency (PC)

- Effectiveness $=28.033+1.899 *$ Personal Competency $($ PerC)

- Effectiveness $=158.254+4.138 *$ Industrial Competency $(\mathrm{InC})$

- Effectiveness $=150.246+2.159 *$ Organizational Competency $($ OC) 
Table 9. Relationships between the project managers' competencies components and effectiveness of project managers

\begin{tabular}{|c|c|c|c|c|}
\hline \multicolumn{2}{|c|}{ Components' Relationships } & \multirow{2}{*}{$\begin{array}{c}\begin{array}{c}\text { The } \\
\text { correlation } \\
\text { coefficient }\end{array} \\
0.317 \\
\end{array}$} & \multirow{2}{*}{$\begin{array}{c}\text { P-value } \\
\text { Less than } 0.001 \\
\end{array}$} & \multirow{2}{*}{\begin{tabular}{|c|}
$\begin{array}{c}\text { Determination } \\
\text { coefficient of } \\
\text { the regression } \\
\text { equation }\end{array}$ \\
\end{tabular}} \\
\hline \multirow{3}{*}{$\begin{array}{l}(\mathbf{K C}) \quad \& \\
(\mathrm{E})\end{array}$} & Pearson's correlation coefficient & & & \\
\hline & Spearman's correlation coefficient & 0.258 & Less than 0.001 & \multirow[t]{2}{*}{0.100} \\
\hline & Kendall's correlation coefficient & 0.176 & Less than 0.001 & \\
\hline \multirow{3}{*}{$\begin{array}{l}\text { (PC) \& } \\
\text { (E) }\end{array}$} & Pearson's correlation coefficient & 0.844 & Less than 0.001 & \multirow{3}{*}{0.712} \\
\hline & Spearman's correlation coefficient & 0.872 & Less than 0.001 & \\
\hline & Kendall's correlation coefficient & 0.744 & Less than 0.001 & \\
\hline \multirow{3}{*}{$\begin{array}{l}(\mathbf{P e r C}) \& \\
(\mathbf{E})\end{array}$} & Pearson's correlation coefficient & 0.674 & Less than 0.001 & \multirow{3}{*}{0.454} \\
\hline & Spearman's correlation coefficient & 0.590 & Less than 0.001 & \\
\hline & Kendall's correlation coefficient & 0.395 & Less than 0.001 & \\
\hline \multirow{3}{*}{$\begin{array}{l}(\mathrm{InC}) \quad \& \\
(\mathrm{E})\end{array}$} & Pearson's correlation coefficient & 0.246 & Less than 0.001 & \multirow{3}{*}{0.060} \\
\hline & Spearman's correlation coefficient & 0.267 & Less than 0.001 & \\
\hline & Kendall's correlation coefficient & 0.199 & Less than 0.001 & \\
\hline \multirow{3}{*}{$\begin{array}{l}(\mathbf{O C}) \quad \& \\
(\mathrm{E})\end{array}$} & Pearson's correlation coefficient & 0.276 & Less than 0.001 & \multirow{3}{*}{0.076} \\
\hline & Spearman's correlation coefficient & 0.256 & Less than 0.001 & \\
\hline & Kendall's correlation coefficient & 0.181 & Less than 0.001 & \\
\hline
\end{tabular}

Also the positive regression coefficient indicates a direct relationship among the effectiveness of project managers and intellectual capital as shown in Table 10. According to the ratio test, managers with good efficacy scores than the 0.91 and P-value is equal to one, so the null hypothesis at the significance 0.05 is rejected. The effectiveness of the project managers are desirable.

Table 10. Relationships between the effectiveness of project managers and intellectual capital components

\begin{tabular}{|c|c|c|c|}
\hline \multicolumn{2}{|c|}{ Components' Relationships } & \multirow{2}{*}{$\begin{array}{c}\begin{array}{c}\text { The correlation } \\
\text { coefficient }\end{array} \\
-0.057 \\
\end{array}$} & \multirow{2}{*}{$\begin{array}{c}\text { P-value } \\
0.420\end{array}$} \\
\hline \multirow{3}{*}{$\begin{array}{l}(\mathbf{H C}) \\
(\mathbf{E})\end{array}$} & Pearson's correlation coefficient & & \\
\hline & Spearman's correlation coefficient & -0.043 & 0.549 \\
\hline & Kendall's correlation coefficient & -0.030 & 0.533 \\
\hline \multirow{3}{*}{$\begin{array}{l}(\mathbf{S C}) \\
(\mathbf{E})\end{array}$} & Pearson's correlation coefficient & -0.065 & 0.358 \\
\hline & Spearman's correlation coefficient & -0.037 & 0.598 \\
\hline & Kendall's correlation coefficient & -0.029 & 0.553 \\
\hline \multirow{3}{*}{$\begin{array}{ll}(\mathbf{R C}) & \boldsymbol{8} \\
(\mathrm{E}) & \end{array}$} & Pearson's correlation coefficient & -0.083 & 0.241 \\
\hline & Spearman's correlation coefficient & -0.066 & 0.352 \\
\hline & Kendall's correlation coefficient & -0.047 & 0.329 \\
\hline \multirow{3}{*}{$\begin{array}{l}\text { (IC) } \quad \& \\
(\mathbf{E})\end{array}$} & Pearson's correlation coefficient & -0.071 & 0.317 \\
\hline & Spearman's correlation coefficient & -0.046 & 0.522 \\
\hline & Kendall's correlation coefficient & -0.033 & 0.491 \\
\hline
\end{tabular}




\section{Discussion and Conclusion}

This study has contributed to the areas of Human Resource Management (HRM), in general, and Project Managers Competency Model (PMC) \& Intellectual Capital (IC), in particular, as it has shed some light on the importance of developing competencies of human resources in organizations. The results of the study indicated a positive and significant effect of the project managers' competencies on the effectiveness of project managers but there is no positive and significant effect of the intellectual capital on the effectiveness of project managers. It means knowledge, performance, personal characteristics, industrial \& organizational knowledge directly affects on achievement of organizational goals in research institutes, as effectiveness, even if these organizations are not powerful and organized in human capital, structural capital and relationship capital. It is obvious that the most successful companies are the ones which know how to make use of this intangible property in a better and fast way. As previously mentioned, intellectual capital is a group of collective mental abilities or key knowledge which can act as a source to increase organizational competence and improve business performance. Unfortunately, the project oriented organizations like research institutes in areas of energy ministry in Iran the main focus is on project management knowledge and expertise rather than management of intangible assets. Intangible assets and intellectual capital are the sources of value and the levers for sustainable business performance in today's competitive economic context. Firms, organizations, as well as governments require tools and techniques to manage, measure, and report their key value drivers. The problem is that most traditional management systems were designed for an era when tangible assets dominated. Accounting systems, as just one example, appear to completely ignore most intangibles and knowledge-based assets.

Project oriented research institutes in Iran's government are so traditional in structure. Because of it, they don't know how to identify the critical value drivers in their organizations, how to visualize and map these inter-relationships, how to measure their intangible assets and integrate those into their corporate performance management systems, how to use knowledge management processes to maintain and grow their knowledge assets and their intellectual capital and how to report and disclose intangible assets and intellectual capital. Despite the problems, there are a number of performance measures of intangible assets presented in the research and it seems that the organizations are also applying them in practice but it is not enough, because the results show they have weakness in the field of intellectual capital management. Despite the reasons, institutions due to having strong and effective human resources, they achieve their goals is determined based on the employee's abilities.

Human capital refers to individual knowledge, skills, experiences and capabilities, whether those pertain to organizational members (Roos, 1998; Stewart, 1997; Youndt et al., 2004; Subramaniam \& Youndt, 2005) that they are knowledge, performance and personal competencies, structural capital represents the of such individual-based knowledge resources into those of the organization, and the regeneration of such knowledge through relational capital (Bontis, 2001). Even if employee's competencies were at its highest, it doesn't mean intellectual capital (or their dimensions like human, structural and relational capital) unless these competencies were been tangible, structured and composed in financial statements. 
Based on study results, the research conceptual model will be in Figure 4. In figure below, solid arrows show relationships between dimensions and long dash arrows show no proven relationships between dimensions according to research results.

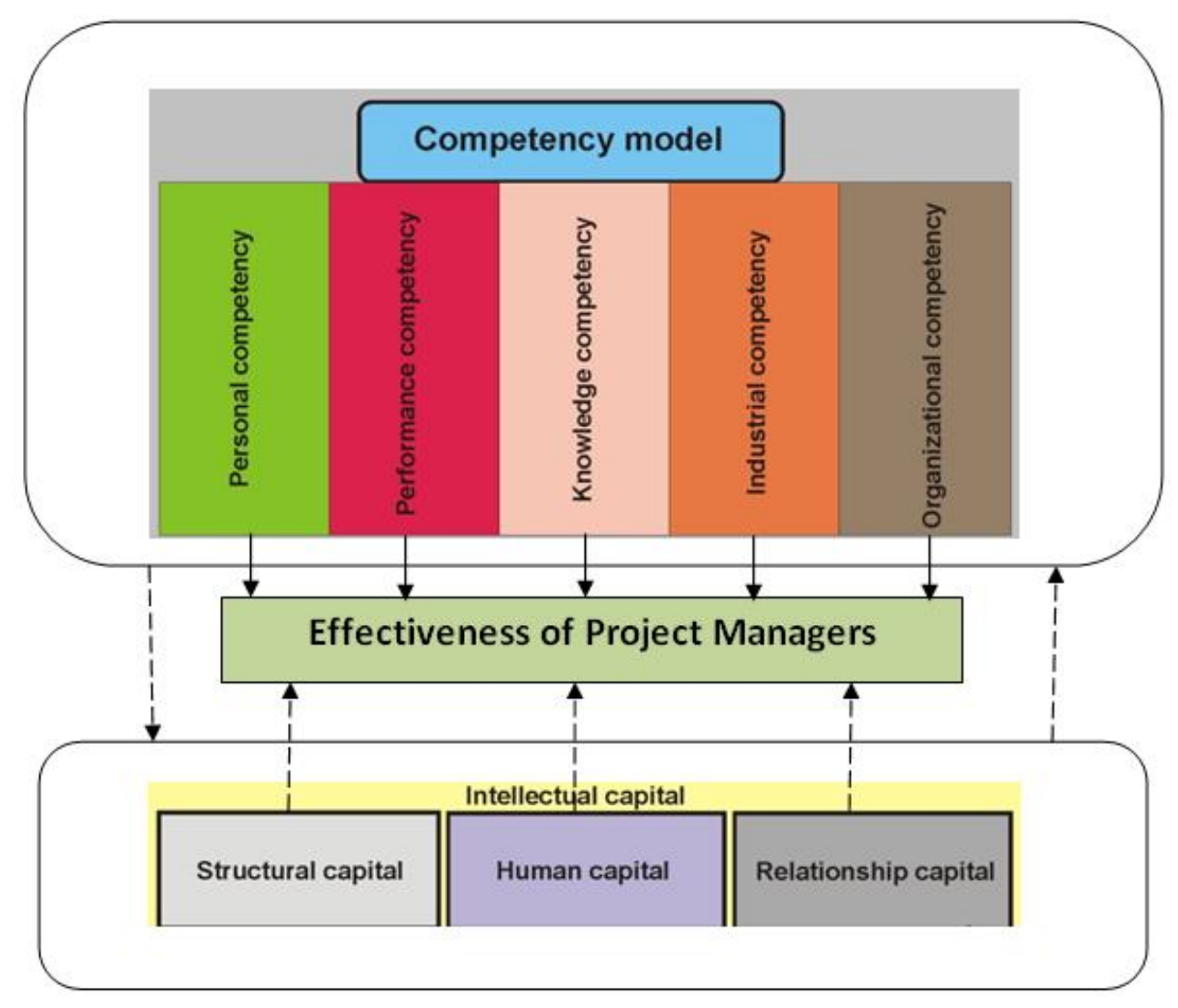

Figure 4. Research conceptual model

The study results are so stable and reliable because we use confident instrument to measure indicators like standard and detailed exams. We have five standard exams to evaluate project managers' competencies that it is not regular in human resource studies in level of thesis and also we use valid and reliable questionnaires to evaluate intellectual capital and effectiveness of project managers. These findings indicate an investment on the human resources play an important role to organization success. The concept intangible success factors is used to refer to individual intangible assets and also the activities related to improving or utilizing the assets, i.e. any intangible phenomena that are to be measured. The ways of research show how organizations can measure some intangible assets like knowledge of employees or effectiveness of them. In addition, the results reveal that research institutes operating in Iran's Energy ministry have knowledge human resources works in traditional structures in which the price is not intellectual capital.

\section{References}

Bernard, M.. (2013). Intellectual capital incorporating intellectual assets; knowledge assets. http://dx.doi.org/10.1057/9781137294678.0322 
Bernard, M. (2008). Impacting future value: how to manage your intellectual capital. published by the society of management accountants of Canada.

Bontis, N. (2001). Assessing knowledge assets: a review of the models used to measure intellectual capital. International Journal of Management Reviews, 3(1), 41-60. http://dx.doi.org/10.1111/1468-2370.00053

Bontis, N, Crossan M. M., \& Holland, J. (2002) Managing an Organizational Learning System by Aligning Stocks and Flows. Journal of Management Studies, 39(4), 437-469.

Boyatzis, R. E. (1982). The competent manager: a model for effective performance. London: Wiley.

Dillman, D. (1978). Mail and Telephone Surveys: The Total Design Method. New York: Wiley.

Edvinsson, L., \& Malone, M. S. (1997). Intellectual Capital. New York: Harper Collins Publishers Inc.

Field, A. (2000). Discovering Statistics Using SPSS for Windows. London: Sage Publications.

Fisher, I. (1930). The theory of interest, as determined by impatience to spend and opportunity to invest. New York, NY: Macmillan Company.

Roos, G., Pike, S., \& Fernstrom, L. (2012). Managing intellectual capital in practice. Routledge.

Gareis, R., \& Huemman, M. (1999). Specific Competencies in the Project-oriented Society. Project Management Days'99: Projects and Competencies, Vienna, 18-19 November.

Global Performance Based Standards for Project Management Personnel. (2003). University of lille, France.

Harrison, S., \& Sullivan, P. H. (2000). Profiting from intellectual capital - learning from leading companies. Journal of Intellectual Capital, 1(1), 33-46. http://dx.doi.org/10.1108/14691930010324124

Hair, J., Anderson, R., Tatham, R., \& Black, W. (1998). Multivariate Data Analysis (5th ed.). Upper Saddle River, NJ: Prentice-Hall.

ICB-IPMA Competence Baseline Version 3.0. (2006). International Project Management Association, 0-9553213-0-1.

Johnson, H. G. (1960). The political economy of opulence. The Canadian Journal of Economics and Political Science, 26, 552-564.

Prakash, K., \& Shinako, P. (2013), How to measure management effectiveness.

Katila, R., \& Ahuja, G. (2002). Something Old, Something New: A Longitudinal Study of Search Behavior and New Product Introduction. The Academy of Management Journal, 45(6), 1183-1194. http://dx.doi.org/10.2307/3069433

Gould, M., \& Freeman, R. (2004). The art of project management: a competency model for 
project managers. Boston university.

Marshall, A. (1961). Principles of economics (9th ed., Variorum). II, Notes, Macmillan Company of Canada, Toronto.

Michelle R. E. (2008). Competency Models: A Review of the Literature and The Role of the Employment and Training Administration (ETA). Employment and Training Administration U.S. Department of Labor.

Mincer, J. (1958). Investment in human capital and personal income distribution. The Journal of Political Economy, LXVI(4), 281-302.

Mulder, M. (2001). Competence Development - Some Background Thoughts. The Journal of Agricultural Education and Extension, 7(4), 147-159.

National park service U.S department of the interior, Human Capital Strategy Competency Development (2010). Concessions Management Advisory Board March.

Ordóñez de Pablos, P. (2004). A Guideline for Building an Intellectual Capital Statement: The 3R Model. International Journal of Learning and Intellectual Capital, 1(1).

Paola L. D. (2007). Project Management Organizational Structures, Management for development series. Retrieved from http:// www.pm4dev.com

Project Management Institute. (2002). Project Manager Competency Development (PMCD) Framework. Newtown Square, Pennsylvania USA.

PMI. (2007). Project Manager Competency Development (PMCD) Framework (2nd ed.). Project Management Institute, Four Campus Boulevard, Newtown Square, PA 19073-3299 USA

Ramezan, J. (2013). Managing Intellectual Capital in Organizations. International Journal of Human Resource Studies, 3(4), 121-127.

Rebecca, A. W. (2002). Project Manager Competency Development Framework. Project Management Institute, Inc. 19073-3299 USA.

Roos, J., Roos, G., Dragonetti, N. C., \& Edvinsson, L. (1997). Intellectual Capital. Navigating the New Business Landscape. Macmillan Press Ltd., Basingstoke and London.

Roos, J. (1998). Exploring the concept of intellectual capital (IC). Long Range Planning, 31(1), 150-153. http://dx.doi.org/10.1016/S0024-6301(97)87431-6

Sandwith, P. (1993). A hierarchy of management training requirements: The competency do main model. Public Personnel Management, 22, 43-63.

Shippman, J. S., Ash, R. A., Battista, M., Carr, L., Eyde, L. D., Hesketh, B., ... Sanchez, J. I. (2000). The practice of competency modeling. Personnel Psychology, 53, 703-740.

Simkovic, M. (2013). Risk-Based Student Loans. Washington and Lee Law Review, 70(1), 527.

Schultz, T. W. (1961). Investment in human capital. The American Economic Review, 1, 1-17. 
Schultz, T. W. (1971). Investing in people: the economics of population quality. Los Angeles: University of California.

Scottish Community Development Centre for Learning Connections, Capacity Building Program, Core Competency Framework. (2007). 5th ed. Supported by Communities and Local Government.

Seleim, A., \& Khalil, O. (2011). Understanding the knowledge management-intellectual capital relationship: a two-way analysis. Journal of Intellectual Capital, 12(4), 586-614. http://dx.doi.org/10.1108/14691931111181742

Stewart, T. (1997). Intellectual Capital: The New Wealth of Organizations. New York: Currency.

Subramaniam, M., \& Youndt, M. (2005). The influence of intellectual capital on the types of innovative capabilities. Academy of Management Journal, 48(3), 450-463 http://dx.doi.org/10.5465/AMJ.2005.17407911

Suha, S. A. (2014). Intellectual capital development and its effect on technical innovation in banks operating in Jordan. Journal of Management Research, 6(1), 211-238. http://www.macrothink.org/journal/index.php/jmr/article/view/4629/4066.

Sveiby, K. E. (1997). The 'Invisible’ Balance Sheet. Retrieved from http://www.sveiby.com

Van Buren, M. (1999). A yardstick for knowledge management. Training and Development Journal, 53(5), 71-78. Retrieved from http://links.emeraldinsight.com/ref/ 28AR234

Wang, W. Y., \& Chang, C. (2005). Intellectual capital and performance in causal models: Evidence from the information technology industry in Taiwan. Journal of Intellectual Capital, 6(2), 222-236. http://dx.doi.org/10.1108/14691930510592816

Weatherly, L. (2003). Human Capital: The Elusive Asset. SHRM Magazine.

Youndt, M. A., Subramaniam, M., \& Snell, S. A. (2004). Intellectual Capital Profiles: An Examination of Investments and Returns. Journal of Management Studies, 41(2), 335-361. http://dx.doi.org/10.1111/j.1467-6486.2004.00435.x

\section{Copyright Disclaimer}

Copyright reserved by the author(s).

This article is an open-access article distributed under the terms and conditions of the Creative Commons Attribution license (http://creativecommons.org/licenses/by/3.0/). 